\title{
REVISITING LATIN exilis
}

In a recent paper on "Una palabra dificil: Lat. exïlis», Emilio Nieto (1987) offers a novel etymology of the Latin adjective exilis 'thin'. Whereas I completely agree with his critique of earlier attempts', I find Nieto's own proposal unconvincing. The reasons for my verdict will become evident in the bulk of the present paper.

\section{Nieto on exīlis.}

According to Nieto, exilis comes from the proto-word *eks-su(e)idslis 'apartado de la suerte o pujanza que proporcionan los astros' (p. 350), which is supposed to be a derivative of the proto-form of sidus 'star'. The original context of situation that suggests itself, according to Nieto, involves the augurium.

1.1. Ph on ology. Given the proto-word *ekssueidslis 'starless', it is not clear at all that the regular outcome by sound-laws would have been exilis, the moot question being whether the string /suei/ yields /si/. Only two cases in point are adduced by Hamp (1975), who is keen on assuming that su- went to $s$ - virtually before any [-low] vowel:

(1) a. si 'if < " suei (from the stem "suo-);

b. sidus < "sueidos/es- (from the root "sueid-).

Neither (la) nor (lb) are clear cases, though. As to (1a), the reconstruction of an initial *su- seems to be called for by the existence of Oscan svai and Umbrian sve 'si', which reflect an old feminine locative *svai (Hamp 1975, p. 64). Notice, however, that the Latin conditional conjunction, whether or not with an intial *su-, is an old masculine/ neuter locative. This morphosyntactic discrepancy entails distinct proto-

' Nieto's inventory of earlier etymological proposals is rather complete. However, there is one serious omission, namely Nyman (1981). 
forms in any event for Latin and Osco-Umbrian, respectively, thus undermining the cogency of the *suei reconstruction. It is simpler to equate Latin $s i$, sei with Volscian se (in se pis 'sì quis'; e. g., Pisani 1953, p. 118 [par. 55]) and trace both back to an old masculine/neuter *se-i. As to (1b), alternative etymologies have been proposed. Pârvulescu $(1977 ; 1980)$ relates sidus to the verb sido $\left(<{ }^{*} s i-z d-o\right)$ "to sit, get down', suggesting that the original meaning of sidus was 'fixed star' $\left(<{ }^{*}\right.$ sidos/es- 'that which is fixed') ${ }^{2}$. More plausible is Rix's (1985) proposal to relate sidus to the PIE root sidh- 'gerade, aufs Ziel gerichtet'. Nyman (1990) presents a wholesale rejection of Pârvulescu's (1980) etymology and a novel explication of the semantic relation between sidus $(<*$ sidh-) and considerare, desiderare.

The string /suei/ is set-theoretically subsumed by /swe/. For the latter, Hamp (1975, pp. 65-66) posits the following steps of change:

(2) /sue $/>$ /suo/ $>$ /so $/$.

What (2) says, in effect, is that the /e/ and /o/ phonemes were neutralized after $/ \mathrm{su} /$ in pre-Latin. Accordingly, the PIE root *sueis- was deemed to give pre-Latin *suoid- which, in turn, went to Latin süd$\left(<{ }^{*}\right.$ soid- $<{ }^{*}$ suoid -$)$. Given the neutralization process formulated in $(2)^{3}$, it is easy to see that Latin sidus cannot possibly be the reflex of PIE *sueid-. Indeed, there are other considerations as well which speak for südor 'sweat' being the Latin reflex of PIE *sueidòs/sueidos > Greek $\varepsilon I \delta \circ \varsigma$ (occurring in the psilotic and itacistic shapes $\varepsilon i \delta \circ \varsigma$ and $l \delta \circ \varsigma$ only) 'heat; sweat'; see Rix (1985). It goes without saying that the relation between Latin südor ( $<{ }^{*}$ sueidōs) and Greek eloos $\left(<{ }^{*}\right.$ sueidos) is the same as that between Latin decor $(<-\overline{o s})$ and decus $(<-o s)$.

If rule (2) is accepted as such without a right-context restriction - and there is no independent reason for such an additional constraint-, it follows that Nieto has to look for another base-form. This is no problem, to be sure, because all he needs is the proto-word *ekssid-slis or *eks-sidh-slis instead of *eks-sueid(h)-slis, and the desired base is provided by Pârvulescu (1977), Rix (1985), and Nyman (1990).

1.2. Morphology. Nieto states: «El supuesto *ekssu(e)idslis ofrece una estructura morfológica conocida, con una ampliación - $s$ - tra-

2 On Pârvulescu's etymology, see Nyman (1990).

${ }^{3}$ Of course, rule (2) could be formulated so as not to allow sue- $>$ suo- if a glide follows. However, there is evidence indicating that Latin diphthongs behaved on a par with a VC string in a closed syllable; witness ${ }^{*} e n+k$ aid $+o>$ inceido ( $>$ incido), * en + fak + tom > infectum. Cf. also Szemerényi $(1960$, p. 235) on Latin vowel contraction. 
dicionalmente propuesta (...) que no es sino el grado reducido del sufijo -es/-os presente en el propio sidus» (p. 350). If sidus could be traced back to PIE *sueidos/es-, it would be possible, indeed, to posit the zerograde stem *sueids-, to which various derivational suffixes could be attached. Nieto's proposal and his examples (iümentum $[<$ iougsmentum], and auxilia [ $<^{*}$ augs-]) suggest that the proto-word be analyzed not as *eks-sueid-slis but as *eks-sueids-lis. However, even if the above discussion were forgotten for the sake of argument, it would be arbitrary to push whatever historically underlies Latin sidus back to PIE, because it obviously lacks a cognate equivalent which would clinch the case for its being traceable back as far as to PIE. What sidus reflects is not a PIE word but a PIE word-type, based on the -os/es- pattern. This is an important methodological point, I think, which tends to be neglected by Indo-Europeanists. The existence of Lat. genus generis $=\mathrm{Gk}$.

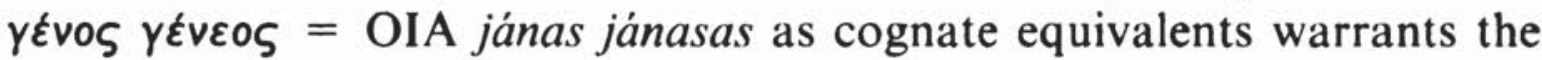
reconstruction of * $\hat{g}$ enos * $\hat{g}$ énesos as a PIE word, and of course as a direct exemplification of the pattern. Whatever underlies sidus must be judged as a pre-Latin word.

Whatever etymologically underlies exilis must also be considered a pre-Latin formation. At this stage («état de langue»), however, the zerograde of the -os/es- nouns was no longer alive as a derivational-morphological device. That is: the tripartite pattern -os/es-/s- was inherited into Latin as -os/es-. The zero-grade -s- was reanalyzed as part of the suffix, giving rise to a wealth of suffix variants (-lis/-slis, -men/-smen, etc.). Although the "psychological reality" of the suffixal reanalysis has never been established beyond any reasonable doubt, the secretional variants -slo- and -sli- have nevertheless been wielded to create etymological miracles, like e. g. prēlum 'press' < *prem-slom; see Nyman (1981, p. 94) on prèlum, scàlae, mälae, quälus, ancìle, mantèle. I surmise Nieto's *eks-sueid-slis involves a proposal of that ilk.

But rather than the form -slis I am worried about the morphological value of the suffix. Nieto does not explain what kind of morphological pattern he thinks that underlies his *eks-sueid-slis. At first blush, one is tempted to compare *amb-kaid-sli and *man-terg-sli, which are usually posited (e. g. by Leumann 1977, p. 208) as underlying ancile 'oval shield' and mantèle 'towel', respectively. These are nouns, however, and probably formed on past participle stems (*amb+kais $+l i$ [cf. caesum /kais + um/, ${ }^{*}$ man + ters + li [cf. tersum /ters + um/]; Nyman 1981, p. 94). Nieto makes a vague suggestion that his *eks-sueid-slis is a derivative of an older substantive *ekssu(e)idslom > *eksilum (p. 350), but this is of no help. He also points to the adjective extorris 'exiled' as a 
parallel. However, the parallelism is confined to the ex-prefix. A clear identifications of the morphological pattern remains lacking.

1.3. Sem a ntics. On the original context of situation Nieto concludes: "Se trataría, pues, de un vocablo más de precedencia rural y augural extendido fuera de su extricto ámbito originario") (p. 350). However, there is nothing to establish augural provenience: firstly, at the time when exilis was coined, the augurium had nothing to do with stars; and secondly, exilis does not occur in augural contexts, even if «augural» were given such a liberal interpretation as that obviously intended by Nieto.

According to Nieto, "el significado originario de exilis es casi antónimo del de félix y aplicado a ager terra, etc.» (p. 349). More or less synonymous with the adjective infellix 'unproductive' (originally colligated only with arbor; Flinck 1921, pp. 48-50), exilis "habría sido aplicado en principio a ager, sōlum, etcétera, con el significado de 'apartado de la suerte o pujanza que proporcionan los astros'» (p. 350). This proto-meaning is supposed to reflect an augural context of situation.

Nieto postulates augural origin obviously in order to rationalize his etymology "exilis a sidere». Because he is so inexplicit, we do not know, whether or not Nieto has in mind the augurium canarium, which involved, according to Flinck (1921, p. 23), a magical ${ }^{4}$ elimination of the heat of the sun and the dryness brought about by the Sirius (canis, canicula). However that may be, it has been made quite evident by Neumann (1976) that originally - and certainly at the time when exilis was formed - the task of the augures was to interpret bird-signs. This etymology presupposes a close conceptual and functional relation between the auspicium and the augurium in that the task of the auspex $\left(<{ }^{*}\right.$ aui $i+$ spek +$)$ was to observe birds and their signs, and that of the augur (<*aui+gus) was to interpret bird-signs (Neumann 1976, p. 226) ${ }^{5}$.

Insofar as the task of the augures was to interpret celestial signs, these signs were believed to be causally related to external climatic fac-

4 Flinck's (1921) views on the magical character of the augurium are now generally rejected (see e.g. Catalano 1960; Linderski 1986). Flinck also entertains an implausible etymology of augur. Connecting this word with the verb augere, he looks upon augures as 'increasers'. A time-honored etymology derives augur from *awi + gus, in which the element gus is the zero-grade of the root * geus + 'select; observe, consider, weigh', the morphological pattern being the same as in con +iux (from the root*ieug + ). See Neumann (1976).

5 To be sure, this was not the case at the republican period (see Cipriano 1983, p. 103 and Linderski 1986, col. 2190-2225). 
tors conditioning the prosperity of the crops (heat of the sun, dryness, etc.) ${ }^{6}$. As far as $I$ have been able to verify ${ }^{7}$, exilis does not occur in syntagms witnessing such contexts. It is true that in a couple of passages exilis is opposed to ferax and laetus, ${ }^{8}$ both of which are roughly synonymous with felix, but nowhere seem climatic factors or 'starblight' (sideratio) ${ }^{9}$ to be involved. The meaning referred to by the syntagm-type «\{ager, sōlum, terra, etc. $\}+$ exilis» surfaces quite nicely in Cic., Leg. agr. II 67 quod solum tam exile et macrum est, quod aratro perstringi non possit. Thus, exilitas soli involves an inherent material quality of the soil, and this was something not causally linked, in the ancient belief-system, to augural or celestial signs. Quite simply, solum exile means 'thinly-layered soil'. Although this syntagm has etymologically transparent semantics, the proto-syntagm must be sought elsewhere.

\section{Unriddling the etymology of exilis.}

I agree with Nieto (p. 349) that the meaning development of exilis must be assumed to have gone from concrete to abstract. Very often, though not unexceptionally - witness e.g. Stern (1931, pp. 352-354) on the origin of Engl. bead 'bead' < 'prayer'-, this is a workable heuristic principle. I also agree that the origin of exilis was rural. But I do not believe that syntagms like ager exilis or solum exile represent the proto-syntagm.

A look at the examples of the solum exile type syntagms given in ThLL V 2, 1482, 8-24 (Beutler) reveals that exilis is mostly opposed to pinguis and crassus, and used as a synonym of ieiunus and macer. What this suggests is that solum exile came about as a metaphor, not unlike solum ieiunum 'starving soil' (cf. Colum., V 5,1 ieiuno atque exili agro).

6 This is summarized by Flinck: «So würden wir zu dem Schluss gelangen, dass den Auguren die Aufgabe gehörte, die der Bodenkultur günstige Witterung hervorzubringen. Das caelum, welches sie beobachteten, wäre also ursprünglich = 'Wetter', 'Witterung' und signa caelestia = 'Witterungszeichen' gewesen" (1921, p. 29).

7 Admittedly I have not tried very hard, since I think the onus lies on Nieto. It is remarkable, indeed, how cavalierly he dismisses a philologically substantiated semantic explication.

${ }^{8}$ Stat., Theb. VII 306-8 hi deseruisse feruntur / exilem Glisanta Coroniamque feracem / messe Coroniam, Baccho Glisanta colentes; Colum., III 1,8 optimum est solum (...) nec exile nec laetissimum, proximum tamen uberi.

${ }^{9}$ A characterization of sideratio is given by Pliny the Elder (Nat. XVII 222). As one peculiar type of star-blight he adduces the heat brought about by the Sirius: proprium tamen siderationis est sub ortu canis siccitatum uapor, cum insita ac nouellae arhores moriuntur, praecipue ficus et uitis. 
This impression is strengthened by the fact that, among the agricultural writers, this syntagm-type is not attested until Columella. Varro nowhere colligates exilis with nouns designating 'soil'. The conclusion to be drawn from this is that the syntagm-type solum exile was not adopted to technical usage - which is bound to be relatively conservative - until the 1st c. A.D. Besides phonology, morphology, and semantics, Nieto runs into difficulties with chronology.

Given rural origin as the premise, the natural thing to do is to consider the use of exilis in earlier agricultural writers. Interesting data is provided by Varro:

(3) a. Rust. II 4,4 sues (...) potius ex his locis, ubi nascuntur amplae quam exiles, pararis;

b. Rust. II 4,13 porci qui nati hieme, fiunt exiles propter frigora et quod matres aspernantur propter exiguitatem lactis;

c. Rust. 2,12 et hic aprum glas cum pascit empticia, facit pinguem, illic gratuita exilem.

It is certainly significant from the etymological point of view that Varro colligates exilis invariably with nouns designating 'pig' (aper, porcus, sus), whereas for 'thinly-layered soil' he would most probably have chosen to use solum tenue (cf. Rust. I 23,2 rectius enim in tenuiore terra ea quae non multo indigent suco [sc. seruntur]). It is not unreasonable to hypothesize that exilis was originally a porcine adjective denoting a lean pig. From this proto-syntagm the use of exilis was then extended to characterizing lean bodies and body-parts in general ${ }^{10}$.

In Nyman (1981, esp. pp. 96-98) I have argued for the age-old «exilis ab ex+ilis" etymology, adducing French efflanqué as a semantic and

in Witness, e.g., Colum., VI 1,1 Campania plerumque boues progenerat albos et exiles; VI 2.15 sed tam uitium est hubulci pinguem quam exilem bouem reddere; Lucil. 332-3 quod deformis senex arthriticus ac podagrosus / est, quod mancus miserque, exilis, ramite magno [see Nyman 1981, pp. 96-97]; Cic., Nat deor. I 123 neque enim tam desipiens fuisset, ut homunculi similem deum fingeret (...) exilem quendam atque perlucidum; Moret. 35 (custos) cruribus exilis; Vitr., I 6,3 aer agitatus (...) efficit ea (sc. vitiosa corpora) exiliora; Hor., Epod. VIII 9-10 femur tumentibus / exile suris additum; Prop., II 22.21 sed tibi si exiles uideor tenuatus in artus, / falleris; Ov., Pont. I 10,27 paruus exiles sucus mihi peruenit in artus; Ov., Met. V 433-4 nam leuis in gelidas membris exilibus undas / transitus est; VI 143 in latere exiles digiti pro cruribus haerent; Sen., Epist. LXXVIII 8 maximi dolores consistunt in macerrimis corporis partibus: nerui articulique et quicquid aliud exile est; Stat., Theb. XI 642 illius exili stridentem in pectore plagam; Plin., Epist. III 6,2 exile collum; Cic., Diu. II 30 sed si eadem hora pecudis iecur nitidum atque plenum est, aliae horridum et exile, quod declaruri possit habitu extorum et colore?; II 37 contactum aliquo morbo bouis exile et exiguum et uietum cor. 
morphological analogue (cf. also Italian sfiancato). Exilis (i.e., ex+ilis) is phonologically problemless, and it represents a well-established morphological pattern, namely ex + NOUN + is 'NOUN + less' (exanimis [anima], ènervis [nervus], exsanguis [sanguis] - and exilis [ilia]). As far as semantics is concerned, "ilia refers precisely to that part of the body in which obesity and leanness is most conspicuous" (Nyman, 1981, p. 97).

To conclude, Nieto's (1987) etymological proposal cannot possibly supersede the etymology which connects exilis with ilia ".

\section{MarTti Nyman}

\section{REFERENCES}

Catalano, P., 1960: Contributi allo studio del Diritto augurale, I, Torino.

Cipriano, P., 1983: Templum, Roma.

Flinck[-Linkomies], E., 1921: Auguralia und Verwandtes, Helsingfors.

Hamp, E. P., 1975: "Latin sidus, sidera», AJPh 96, pp. 64-66.

Leumann, M., 1977: Lateinische Laut- und Formenlehre, München.

Linderski, J., 1986: "The Augural Law», $A N R W$ II 16,3, col. 2146-2312.

Neumann, G., 1976: «Zur Etymologie von lateinisch 'augur'» WüJA (N. F.) 2, pp. 219-230.

Nieto, E., 1987: "Una palabra dificil: Lat. exïilis», EMERITA 55, pp. 345-351.

Nyman, M., 1981: «Deleting a Lautgesetz: Lat. exilis and relates issues», Arctos 15 , pp. $85-99$.

- 1990: "Hits and misses: Lat. considerare and desiderare», $K Z 103$.

Pârvulescu, A., 1977: "Le nom indo-européen de l'étoile'», $K Z$ 91, pp. 41-50.

- 1980: "Latin considerare et desiderare», KZ 94, pp. 159-166.

Pisani, V., 1953: Le Lingue dell'Italia Antica oltre il Latino, Torino.

Rix, H., 1985: "Südor und sidus", Sprachwissenschaftliche Forschungen, Festschrift für Johann Knobloch (ed. by H. M. Ölberg \& al.), pp. 339-350, Innsbruck.

Stern, G., 1931: Meaning and Change of Meaning, Gothenburg.

Szemerényi, O., 1960: «Etyma Latina I (1-6)», Glotta 38, pp. 216-251.

1 For further details, I refer the patient reader to Nyman (1981). 